\title{
Reflex Vasoconstriction to a Cold Stimulus for Non-Invasive Evaluation of Neurovas- cular Function in Man
}

\author{
Yoshifusa Aizawa, M.D., Akira Shibata, M.D., Masaki TajiRI, M.D., \\ and Yoshihei Hrrasawa, M.D.
}

\begin{abstract}
SUMmaRY
The response of limb blood flow to cold stimulus was determined by venous occlusion technique in 30 healthy subjects. The stress was applied by immersing one hand into ice-floating water for $35 \mathrm{sec}$, and the blood flow was measured serially in the contralateral upper limb. The change of blood flow at the 15 th sec of stress was the largest among the intermittent measurements, and decreased by $48 \pm 8 \%$ of the control value. A significant rise in plasma dopamine-beta-hydroxylase was found in response to the same stress. This simple cold stress test may be used to evaluate the function of the reflex arc involved in reflex vasoconstriction.

A significantly diminished vasoconstriction was observed in 12 uremic patients with a concomitantly smaller rise of plasma dopamine-betahydroxylase activity in the test.
\end{abstract}

\section{Additional Indexing Words :}

Limb blood flow Somatic or autonomic nerve function Vascular reactivity

\begin{abstract}
A
measurement of limb blood flow by venous occlusion technique has some merits especially in clinical use. ${ }^{1,2)}$ Because it requires only about $5 \mathrm{sec}$ for each measurement, the rapid response to some physiological stimuli will be detected non-invasively with ease. It seems probable that any lesions in the reflex arc will bring an abnormal, usually diminished response. ${ }^{31}$ This paper is concerned with the determination of the response of limb blood flow to a cold stimulus to evaluate the nervous or vascular function involved in reflex vasoconstriction in man.
\end{abstract}

\section{Materials and Methods}

Limb blood flow was measured in the upper limb by venous occlusion tech-

From the First Department of Internal Medicine, Niigata University School of Medicine and Shinrakuen Hospital, Kidney Center, Niigata.

Address for reprints: Dr. Yoshifusa Aizawa, First Department of Internal Medicine, Niigata

University School of Medicine, Asahimachi, Niigata 951, Japan.

Received for publication August 25, 1978.

Manuscript revised January 10, 1979. 
nique in apparently healthy 30 subjects. A physical examination disclosed no abnormality and blood pressure was within normal range (both systolic and diastolic pressures were below $140 \mathrm{mmHg}$ and $90 \mathrm{mmHg}$ ). The age was 43 years in the average ranging from 20 to 60 years. Thirteen were female.

The subject lay supine on a comfortable bed and put his arm into a hard tube to the level of elbow joint. The gap between the rim of the hard tube and the arm skin was sealed by a soft rubber tube. The absence of air leakage was assured and a calibration was done before the measurement. The reproducibility or the reliability was reported elsewhere. ${ }^{3 /, 4)}$ The veins were occluded in the upper arm by inflating a cuff to a pressure of $50 \mathrm{mmHg}$ which was maintained for $5 \mathrm{sec}$, while the blood flow was measured. A volume change following the venous occlusion was detected by a pneumoplethysmograph (Fukuda Denshi, FM-10) and recorded on a photocorder(Fukuda Denshi, Photocorder). The blood flow was expressed in $\mathrm{ml} / \mathrm{min} / 100 \mathrm{ml}$ of limb volume. The study was performed in a quiet room where temperature was kept around $25^{\circ} \mathrm{C}\left(25 \pm 1.5^{\circ} \mathrm{C}\right)$.

After measurement of control blood flow, the other hand was placed in icefloating water for $35 \mathrm{sec}$ (cold stress test). The decrease of blood flow was measured at the 15 th and 30 th sec during the stimulus. The measurement was repeated 3 times at intervals of $1 \mathrm{~min}$ to see the recovery of blood flow after the cold stress. The blood flow at the 15th sec during the stimulus was expressed as percentile change to the resting blood flow and defined as reactivity index to a cold stress. This index was expected to reflect the function of the reflex arc involved in reflex vasoconstriction.

As another evidence of the adrenergic nerve activity in the cold stress test, plasma dopamine-beta-hydroxylase was determined in 8 healthy subjects, too. Blood was obtained before and at the end of the application of cold stimulus to one hand for $1 \mathrm{~min}$. Before the initial blood sampling, they had an enough bed rest. The activity of this enzyme was assayed by the method of Nagatsu et al. ${ }^{5}$ )

As a clinical application, 12 uremic patients were added to the study because frequent dysfunction of autonomic nervous system had been reported in the renal failure patients. ${ }^{6), 7)}$ They were dialysed 3 times a week for $17 \pm 11$ months (mean \pm $\mathrm{SD})$. The serum creatinine level was $13.4 \pm 4.0 \mathrm{mg} / 100 \mathrm{ml}$. Hematocrit was $22.0 \pm$ $6.0 \%$. Serum levels of electrolytes were as follows, $\mathrm{Na}=140 \pm 3 \mathrm{mEq} / \mathrm{L}, \mathrm{K}=4.6 \pm$ $0.3 \mathrm{mEq} / \mathrm{L}, \mathrm{Cl}=103 \pm 5 \mathrm{mEq} / \mathrm{L}, \mathrm{Ca}=4.2 \pm 0.2 \mathrm{mEq} / \mathrm{L}$. $\mathrm{PH}$ was $7.39 \pm 0.03$ and bicarbonate was $20.0 \pm 1.7 \mathrm{mEq} / \mathrm{L}$. These values were determined in the blood sampled before each hemodialysis. The age was $41 \pm 18$ years and 2 were female.

The statistical analysis was done by Student's t-test(paired or non-paired).

\section{Results}

The change of limb blood flow to the cold stress. The resting blood flow was $5.0 \pm 1.4 \mathrm{ml} / \mathrm{min} / 100 \mathrm{ml}$ of limb volume in healthy subjects. It decreased significantly during the stimulus with a gradual recovery to the initial level after termination of the stimulus. The percentile change to the resting value was presented in the Figure. The reactivity index defined as the percentile change to the resting blood flow was $48 \pm 8 \%$ at the 15 th sec of the 


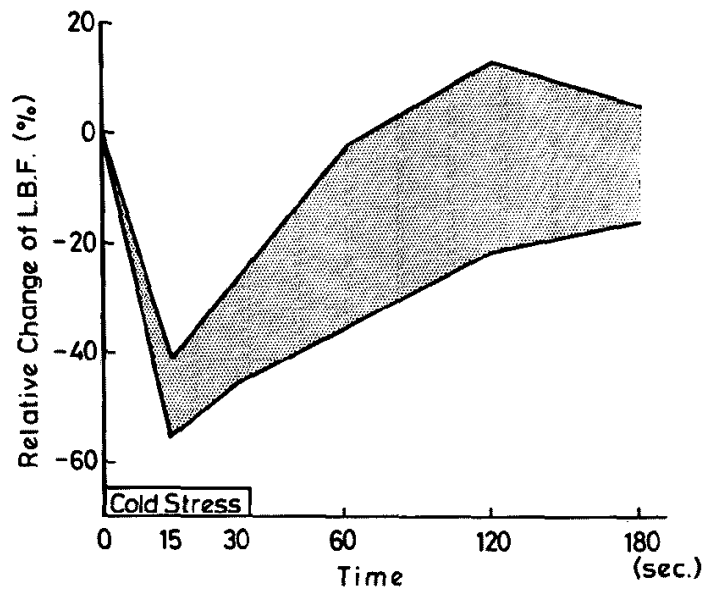

Figure. The serial response of limb blood flow to a cold stress in 30 healthy subjects were presented. A cold stimulus was given at time 0 after measurements of the control level of blood flow and terminated at time $35 \mathrm{sec}$. A relative change to the resting level was expressed in percent. The shaded area represents this relative change in mean $\pm \mathrm{SD}$. A decrease at the 15 th $\mathrm{sec}$ or 30 th $\mathrm{sec}$ during the cold stress was significant which was followed by a gradual increase of blood flow to the control level. The decrease at the 15 th sec showed a narrow range of $\mathrm{SD}$ and it was the largest among the intermittent measurements. This decrease due to reflex vasoconstriction was defined as the reactivity index to a cold stress. L.B.F. = limb blood flow.

Table I. The Responses of Limb Blood Flow and Plasma Dopamine-Beta-Hydroxylase to a Cold Stress

\begin{tabular}{l|c|c|c|c} 
& Control Blood Flow & $\begin{array}{c}\text { Change in \% } \\
\text { at } 15 \mathrm{th} \mathrm{sec}\end{array}$ & Control DBH & Change in DBH \\
\hline $\begin{array}{c}\text { Healthy } \\
\text { subjects }\end{array}$ & $5.0 \pm 1.4 \mathrm{ml} / \mathrm{min} / 100 \mathrm{ml}$ & $\begin{array}{c}48 \pm 8 \% \\
\mathrm{~N}=30\end{array}$ & $28.7 \pm 7.2 \mathrm{IU} / \mathrm{L}$ & $6.1 \pm 4.8 \mathrm{IU} / \mathrm{L}$ \\
$\begin{array}{c}\text { Patients } \\
\text { (uremic) }\end{array}$ & $5.5 \pm 1.7 \mathrm{ml} / \mathrm{min} / 100 \mathrm{ml}$ & $\begin{array}{c}33 \pm 13 \% * \\
\mathrm{~N}=12\end{array}$ & $13.6 \pm 7.6 \mathrm{IU} / \mathrm{L}^{*}$ & $1.6 \pm 1.4 \mathrm{IU} / \mathrm{L}^{* *}$ \\
* & & & \\
$=\mathrm{N}=0.001, \quad * *=\mathrm{p}<0.01$ &
\end{tabular}

stimulus. Though a significant decrease was observed in the uremic patients, the reactivity index to the cold stress was $33 \pm 13 \%$ which was significantly less than that of healthy control group $(\mathbf{p}<0.001)$. The resting blood flow of the patient group was statistically not different; $5.5 \pm 1.7 \mathrm{ml} / \mathrm{min} / 100 \mathrm{ml}$ of limb volume.

The response of plasma dopamine-beta-hydroxylase activity. Following the cold stimulus, the enzyme activity increased by $6.1 \pm 4.8 \mathrm{IU} / \mathrm{L}$ from the resting value of $28.7 \pm 7.2 \mathrm{IU} / \mathrm{L}$ in healthy subjects. The resting value of dopamine-beta-hydroxylase activity in the patient group was significantly 
lower; $13.6 \pm 7.6 \mathrm{IU} / \mathrm{L}(\mathrm{p}<0.001)$. The increase of the enzyme activity was significantly less in these patients; $1.6 \pm / 1.4 \mathrm{IU} / \mathrm{L}(\mathrm{p}<0.01)$. These results were summarized in the Table.

\section{Discussion}

It is worthy to know the nerve and vascular functions in man because some diseases affect them as well as their humoral or hormonal environment. ${ }^{3), 6)-8)}$ During cold pressor test, continuous monitoring of blood pressure by arterial puncture is essential for the detection of rapid change which may occur in the test. ${ }^{91}$ The indirect method will require $1 \mathrm{~min}$ or more for the precise measurement of blood pressure. ${ }^{10}$ The increase of blood pressure by a cold stimulus was 10 to $20 \mathrm{mmHg}$; about $10 \%$ of the control level in healthy subjects. ${ }^{9)}$ The limb blood flow was found to decrease by $50 \%$ of the control value with a concomitant rise of plasma dopamine-beta-hydroxylase by about $20 \%$ from the control level. This reflex vasoconstriction will be therefore useful for evaluation of adrenergic nerve function or vascular reactivity. ${ }^{3}$ When this test was applied to uremic patients, the reactivity was found to be dimished significantly. The response of plasma dopamine-betahydroxylase was also diminished in these patients. From the fact that the reactivity was highly correlated with the level of blood pressure; most diminished in the hypotensive patients, or that both the reflex vasoconstriction and the response of dopamine-beta-hydroxylase to postural change were depressed, dysfunction of autonomic nervous system was strongly suggested in these patients. ${ }^{3,7)}$ Combining with the measurements of plasma norepinephrine or dopamine-beta-hydroxylase, or with evaluation of somatic nervous function, the site of lesions in the arc involved in reflex vasoconstriction will be determined by the present cold stress test. The present method will be useful especially for evaluation of the neural function or the vascular reactivity.

\section{REFERENCES}

1. Kramer K. Lochner W, Wetterer E: Methods measuring blood flow. in Handbook of Physiology, Circulation Vol II, ed by American Physiological Society, Washington DC, p1277, 1962

2. Hsieh ACL: The cutaneous circulation. in The Peripheral Girculation, ed by Zelis $R$, Grune \& Stratton, NY, P79, 1975

3. Aizawa $\mathrm{Y}$, Yuasa $\mathrm{Y}$, Hirasawa $\mathrm{Y}$, et al: Diminished vascular reactivity to a cold stress in the azotemic patients. J Dialysis 1: 781, 1977

4. Aizawa $Y$, Ohmori $Y$, Hirasawa $Y$ et al: A depressant action of acetate upon the human cardiovascular system. Clin Nephrol 8: 477, 1977 
5. Nagatsu T, Udenfriend S: Photometric assay of dopamine-beta-hydroxylase in human blood. Clin Chem 18: 980,1972

6. Lilley IJ, Goldon J, Stone RA: Adrenergic regulation of blood pressure in chronic renal failure. J Clin Invest 57: 1190, 1976

7. Tajiri M, Aizawa $Y$, Hirasawa $Y$, et al; Autonomic nerve dysfunction in patients on longterm hemodialysis. Nephron 23: 10, 1979

8. Thomas PK, Rascelles RG: The pathology of diabetic neuropathy. Quart J Med 35: 489, 1966

9. Hines EA: The significance of vascular hyperreactivity as measured by the cold pressor test. Am Heart J 19: 408, 1940

10. Kirkendol WM, Burton AC, Epstein FH, Freis ED: Recommendations for human blood pressure determinations by sphygmomanometer. Circulation 36: 980, 1967 